\title{
Point to non-point phosphorus trading in the South Nation River watershed
}

\author{
D. O'Grady \\ General Manager, South Nation Conservation, Canada
}

\begin{abstract}
The South Nation River watershed has a regulated water quality trading program. By law, waste water dischargers must discharge $0 \mathrm{~kg}$ of phosphorus (P) loadings into receiving waters. New wastewater systems are now choosing trading instead of traditional $\mathrm{P}$ removal technology. These point source dischargers are buying $\mathrm{P}$ credits from rural landowners, primarily farmers. These credits are generated by constructing non-point source pollution control measures, and calculating the $\mathrm{kg}$ of $\mathrm{P}$ removed by each measure. South Nation Conservation, a community based watershed organization, is the broker for these $\mathrm{P}$ credits. The program is run by a multi-stakeholder committee, and all project field visits are done by farmers and not paid professionals.
\end{abstract}

Keywords: water quality trading, phosphorus trading, water credit trading, watershed trading.

\section{Introduction}

South Nation Conservation (SNC) is a community based watershed organization set up to manage the natural resources of the South Nation River watershed. Over the last several years, SNC paid over $\$ 1$ million in grants to rural landowners for various non-point source pollution control projects.

The South Nation River watershed is located southeast of Ottawa, Ontario Canada. The 4,000 sq. km. watershed has a population of 125,000 , and is mixed farming with dairy, cash crop corn and soybeans predominant.

The South Nation River has peak flows of over 1,000 cu. m./s. in the spring freshet, and less than $20 \mathrm{cu}$. m./s. during summer low flows. There are currently 16 wastewater lagoons in the watershed (14 municipal, 2 industrial). Provincial guidelines allow the lagoons to discharge their effluent at peak flows, primarily in the spring, for dilution of effluent to meet Provincial water quality guidelines. 
The South Nation watershed exceeds Provincial water quality guidelines for $\mathrm{P}$, which is currently $0.03 \mathrm{mg} / \mathrm{L}$. Annual mean $\mathrm{P}$ concentrations for the main South Nation River are $0.07 \mathrm{mg} / \mathrm{L}$ in the upper reach, $0.126 \mathrm{mg} / \mathrm{L}$ in the middle, and 0.129 in the lower reach of the River. Watershed studies show that $90 \%$ of the P load comes from non-point sources (NPS).

The Provincial Ministry of Environment (MOE) is responsible for water quality and licensing the operation of wastewater treatment in the Province. According to Provincial policy, where water quality does not meet Provincial standards for a specific contaminant, no further degradation of water quality will be allowed for that contaminant. However, in the past MOE gave dischargers a permit to discharge $\mathrm{P}$ from their plants into the South Nation River and its tributaries, even though the watercourses did not meet Provincial water quality objectives. Beginning in 1998, the Ministry stopped issuing these permits and required all dischargers to have zero discharge of $\mathrm{P}$ from their plants. $\mathrm{MOE}$ imposed this standard on new construction only. Existing plants that continued to operate according to their current permits required no changes to $\mathrm{P}$ loadings.

In the past, the only option for municipalities to meet this standard was improved wastewater treatment. However, it is not always technically feasible, physically possible, or socially desirable (because of costs) to meet the $0 \mathrm{~kg}$ standard.

MOE therefore allowed an innovative solution to remove $\mathrm{P}$ contributed by wastewater dischargers. Called Total Phosphorus Management (TPM), it allows dischargers to contribute $\mathrm{P}$ from their treatment plants, in contravention of Provincial policy, if they offset this increased P load by controlling P from nonpoint sources (NPS). To reduce $\mathrm{P}$, the point sources buy $\mathrm{P}$ credits from nonpoint sources of pollution.

MOE treats the watershed as a unit. Since $\mathrm{P}$ is contributed throughout the watershed, it allows the TPM program to remove $\mathrm{P}$ anywhere in the watershed. A treatment plant discharging $\mathrm{P}$ in the lower reaches of the watershed can therefore pay to reduce $\mathrm{P}$ in the upper reaches, or any other part, of the watershed.

The number of kilograms of $\mathrm{P}$ to be bought depends on two factors. The first is the amount of $\mathrm{P}$ that the discharger contributes. For example, a village expanding their wastewater plant for an additional 3,500 people will add about $600 \mathrm{~kg}$ of $\mathrm{P}$ into the River. A recent landfill expansion added $25 \mathrm{~kg}$ of $\mathrm{P}$.

The second factor is determined by the offset ratio. In theory, a discharger only needs to reduce $\mathrm{P}$ from non-point sources equivalent to the amount they contribute (i.e. a 1:1 ratio). However, MOE requires a 4:1 ratio for TPM. That is, $4 \mathrm{~kg}$ of $\mathrm{P}$ must be removed from non-point sources for every $1 \mathrm{~kg}$ of $\mathrm{P}$ contributed from a point source. This higher ratio is due to the unique nature of the TPM program (it is the first of its kind in Ontario), lack of knowledge on how much $\mathrm{P}$ is first transported, then delivered, to watercourses, and the debate on how much of the $\mathrm{P}$ in the water is soluble vs. particulate. The high offset ratio also allows a buffer in the event that a BMP is not $100 \%$ effective.

The amount of $\mathrm{P}$ contributed by various non-point sources is determined by formulae derived from studies in Canada and elsewhere. A study of the 
scientific literature published by South Nation Conservation in 2003 shows that the range in results for individual practices is quite large, and the results are highly variable since calculating $\mathrm{P}$ lost or saved by agricultural management practices is complicated. Since 2003 there have been other studies published on $\mathrm{P}$ reduction using various BMP measures, and these will be evaluated by SNC in the near future.

Following are examples of formulae used to calculate $\mathrm{P}$ removal from various NPS control methods.

\subsection{Milkhouse washwater}

Milkhouse washwater refers to the wastewater generated from cleaning the milking equipment, pipeline and bulk tank. It may include cleaning the milk parlour floor, which may contain manure, bedding and feed. P loadings depend on the number of cows, volume of washwater, type of milking system, detergents and management in the milking parlour.

$$
\begin{aligned}
& \text { P controlled by milkhouse washwater (excluding manure) projects } \\
& =\# \text { cows } X 0.69 \mathrm{~kg} . \mathrm{P} / \mathrm{cow} / \mathrm{yr} \\
& \text { P controlled by milkhouse washwater (including manure) projects } \\
& =\# \text { cows } X 2.76 \mathrm{~kg} . P / \mathrm{cow} / \mathrm{yr}
\end{aligned}
$$

\subsection{Manure storage}

The manure storage formula calculates $\mathrm{P}$ savings for proper manure storage. This may include construction of a concrete basin to replace stacked dairy manure piles, berms, a settling basin, or a buffer strip to treat feedlot manure. Two formulae are used: one for beef feedlots and one for dairy manure pile. It is assumed that $\mathrm{P}$ losses from feedlot manure are higher than piled manure since it is spread out and more exposed to rainfall, resulting in more clean water contamination.

$$
\begin{aligned}
& P \text { controlled by proper manure storage of beef feedlot manure } \\
& =\# \text { of animals } X \# \text { days } X P \text { excreted } X 0.30 \\
& P \text { controlled by proper manure storage of dairy pile manure } \\
& =\# \text { of animals } X \text { days } X P \text { excreted } X 0.07
\end{aligned}
$$

\subsection{Clean water diversion}

Clean water diversions control manure runoff from barnyards, feedlots, and manure storage areas. It diverts clean water away from these areas using berms, eavestroughing or roofs and thus reduces P loadings in runoff. The number and type of livestock, size of yard and yard surface as well as the proximity to a watercourse will determine the amount of $\mathrm{P}$ delivered to a watercourse. The following calculation assumes that clean water diversion will control $50 \%$ of the $\mathrm{P}$ lost in runoff. The number of days refers to the number of days that manure or animals are on the yard. 
$P$ savings from clean water diversion for feedlot manure

$=\#$ animals $X$ days X $P$ excreted $X 0.30 X$ (reduced feedlot runoff volume/original feedlot runoff volume)

for dairy pile, replace 0.30 with 0.07

\subsection{Livestock access}

Information on the input of $\mathrm{P}$ from direct livestock access to watercourses is rarely calculated. Studies generally group $\mathrm{P}$ non-point sources (erosion, manure) and do not break down P load reductions into its components. An estimated 3\% of daily manure production is discharged directly into a stream when there is no alternative water source.

$P$ savings from restricted livestock access

$=$ \# of animals $X$ days $X$ phosphorus excreted $X 0.03$

\subsection{Septic systems}

Only repair or replacement of biologically failed systems will produce a $\mathrm{P}$ savings that can be traded. Failed systems are often observed with ponding on the surface. P load savings for improved septic systems are:

$P$ savings $=P$ loading (failed) $-P$ loading (functional),

Where $P$ loading (failed or functional) $=0.6 \mathrm{~kg}$. TP $\mathrm{ca}^{-1} \mathrm{year}^{-1} X$ (\# persons) $X(1-A)$,

Where $A$ = attenuation in vadose zone (0 - failed; 0.4 functional sand; 0.7 - functional sand mixed with either silt, clay or red mud)

\subsection{Conservation tillage}

There is some debate in the literature as to whether conservation tillage increases or decreases $\mathrm{P}$ delivery from cropped fields. Overall it appears that conservation tillage reduces total $\mathrm{P}$, although the soluble $\mathrm{P}$ delivery may increase. Studies show that conservation tillage reduces soil loss and total phosphorus. Various studies show that each hectare of cropland contributes $1 \mathrm{~kg}$ of $\mathrm{P}$ per year. A conservative $50 \%$ reduction is $\mathrm{P}$ is used for no-till.

$P$ controlled per year by no-till $=0.5 \mathrm{~kg} X$ hectares

$P$ controlled per year by cover cropping $=0.4 \mathrm{~kg} X$ hectares

\subsection{Buffer strips}

Buffer strips are areas of planted or naturally occurring vegetation that filters nutrients and sediments from agricultural runoff before it reaches surface waters. Buffer width is the most important factor in removing $\mathrm{P}$.

$P$ controlled per year by buffer strip $=0.67 \mathrm{~kg} X$ ha cropland buffered 


\section{Costing of $P$ removal}

The total cost of controlling each $\mathrm{kg}$ of $\mathrm{P}$ was determined by South Nation Conservation (SNC). Using the formulae above, it was possible to calculate the amount of $\mathrm{P}$ controlled for a number of projects recently completed by SNC. Since the total cost of each project was known, it was possible to derive an average cost of $\$ 400(\mathrm{Cdn})$ for each $\mathrm{kg}$ of P removed. Obviously, some projects are more efficient at controlling $\mathrm{P}$ than others, however the $\$ 400$ figure is accepted as accurate.

The $\$ 400$ also includes costs of project management (staffing, administration), water sampling, communications to promote the grants available to landowners, and yearly reporting. SNC must complete a yearly report showing the amount of $\mathrm{P}$ controlled that year, and allocating that $\mathrm{P}$ to each of the TPM dischargers.

Cost benefit studies done in the South Nation watershed show that the cost for complete removal of $\mathrm{P}$ using traditional wastewater treatment methods can be as high as \$20 million if a new treatment plant is required, to a low of several thousand dollars per kilogram if additional secondary treatment is added to a lagoon (sand filters, treatment wetlands, for example).

The advantages of using the TPM approach are evident:

1. It saves local tax dollars since new wastewater treatment plants are not required to control $P$.

2. It saves government dollars, since wastewater treatment costs are lower, and fewer government grants are needed.

3. It puts money in the hands of farmers.

4. It achieves greater water quality benefits since NPS controls will prevent not only P from entering the water, but other nutrients and pathogens as well.

Most TPM agreements have a four year deadline to reduce the full amount of P. Single municipalities have paid up to $\$ 500,000$ to SNC for P credits.

SNC is the broker between the point source and non-point source, handles all financial transactions between the two, and reports on compliance for P control. Publicity for projects is made through the local media and presentations to municipalities and farm organizations. All projects are voluntary, with no landowner forced to participate in the TPM program.

Neither SNC, nor the landowners as the recipient of the funds, have any legal responsibility should $\mathrm{P}$ targets not be met. This responsibility rests solely with the discharger who must prove to MOE that they meet their P reduction targets. With SNC's experience in grants for similar projects in the past, there is no forecasted shortage of $\mathrm{P}$ reduction projects for several more years.

The issue of responsibility for $\mathrm{P}$ reduction was a key issue to the success of the TPM program. Initially, the agricultural community opposed TPM. They had concerns with several components of the strategy including:

- low offset ratio for P reduction: initial ratio was 2:1

- low funding level per kilogram P removed: initial costs did not include sampling, reporting, communications, all administrative costs

- responsibility of landowners who accept funding to complete non-point projects: it wasn't clear if farmers were to be blamed 
- $\quad$ responsibility of the municipality/industry if the $\mathrm{P}$ offset was not achieved through non-point source reduction projects.

The agricultural community felt dischargers had a license to pollute, and that the public would perceive that farmers were the cause of the problem if they were doing all the work and getting all the grants.

Extensive consultation with the agricultural community over three years achieved consensus on the roles and responsibilities for the various partners involved in the TPM program. This consensus became a Statement of Roles and Responsibilities document that was signed by the local agricultural organizations, Provincial government, and SNC. Consultation also resulted in a higher ratio for $\mathrm{P}$ reduction, higher costs per $\mathrm{kg} \mathrm{P}$ removed, improved water quality monitoring and an overall program evaluation after 5 years.

While water quality trends show a reduction of $\mathrm{P}$, it is not possible to attribute this solely to the TPM program. Watersheds are complex ecosystems, and water quality changes can be attributed to a number of factors, including fertilizer prices, rainfall changes, different tillage practices, etc.

However it is accepted that the $\mathrm{P}$ reduction targets are being achieved. The mathematical formulae are accepted as sound science since they originate from peer reviewed literature.

The consultation process also created a multi-stakeholder Clean Water Committee that approves all projects. The Committee is composed of farmers, industry, municipalities, farm organizations, and SNC. It reviews projects, and whether or not they meet the criteria for funding. All criteria, grant rates, and other water quality decisions are made by the committee. The Committee receives funding from several different sources, all with slightly different funding criteria. It then decides if the landowner project meets the criteria for one of the grant programs.

A final result of the agricultural consultation was the use of farmers as field representatives to do all site visits. The agricultural community expressed some concern over using agency staff who might not understand current farming practices. Now, when a landowner applies for a grant, they contact SNC, who then refers the call to one of several Farmer Field Representatives who then do the field inspection. These Representatives review the project and potential grants with the landowner, and determines if it is indeed eligible for grants. The Field Representative then makes a presentation to the Clean Water Committee, who rank projects based on improvements to water quality. This approach is rare amongst other water quality programs in North America, which tend to use full-time professional staff to do field inspections.

\section{Conclusion}

A point to non-point trading program exists in the South Nation Watershed. South Nation Conservation, a community-based watershed agency, acts as a broker for the program. Wastewater treatment plants are required, by regulation, to discharge $0 \mathrm{~kg}$ of phosphorus for new or expanded wastewater treatment plants. The amount of phosphorus removed is calculated using mathematical 
formulae, and dischargers must remove $4 \mathrm{~kg}$ of phosphorus for every $1 \mathrm{~kg}$ discharged into watercourses. The use of a trading program improves water quality over traditional wastewater treatment other pollutants are removed by the non-point pollution control methods, and not just phosphorus. It also reduces costs to all levels of government since a trading program is a low cost alternative to phosphorus removal. Finally, trading puts more money into the hands of farmers to improve the environment.

The agricultural community had initial reservations on the program, since they felt they would be blamed if phosphorus reduction targets were not met. However a signed agreement between farmers and regulators placed responsibility with the wastewater discharger.

The program is delivered by full-time farmers, who perform all interactions with other farmers. All decisions are made by a multi-stakeholder Clean Water Committee. 